\title{
Discussing the Relative Independence and Dynamic Functions of Morality
}

\author{
Jiguo Pang \& Jianmin Dong \\ Dezhou University, Shandong 253023, China \\ E-mail: djm6513@163.com
}

Received: December 14, $2010 \quad$ Accepted: December 28, $2010 \quad$ doi:10.5539/ass.v7n6p203

\begin{abstract}
To study the moral issues, social and economic relations determining morality must be first grasped and the relative independence of morality and its dynamic functions or roles on society and economy should also be fully understood. Dynamic roles of morality express the relative independence of morality. Fully and correctly comprehending the moral issues is of great significance for us to correctly understand the importance and urgency of socialist moral construction in the context of socialist market economy and the moral transformation as well.
\end{abstract}

Keywords: Morality, Relative independence, Dynamic function

Moral issues are long and historic. Exploring and understanding the special social and moral phenomena should first begin from the origin of morality, that is, the interaction between society and economy. On the one hand, social and economic relation determines the morality; on the other hand, morality, once it comes into being functions dynamically on social and economic relations. To understand all aspects of the morality regularly, attention must be paid to revealing the relative independence of the moral phenomena, the concrete interactions between morality and the specific field of superstructure such as politics, law, literature and art, religion and other factors, that is, the import aspects of special social essence of morality. On this basis, we can have a clearer understanding of the moral transition and development and the positive roles in the context of socialist economy.

\section{The relative independence of morality}

Labor of human beings in the early era and the simple communication gave birth to morality and its historical development and function can not avoid the social and material life, which determines the relative independence of morality. Therefore, the so-called relative independence of morality mainly means that in the social life morality is not completely passive, but relatively positive and independent. And it cannot ultimately go beyond social and material living conditions. This relative independence of morality displayed in all aspects of social and material life needs understanding respectively.

1.1 There exists inconsistency in the moral and social development and the growth of material life conditions. It appears in two aspects in the development of productive force and production relations

1.1.1 Moral development and transformation, in general, tends to lag behind the changes in social material conditions

When a new economic relation replaces the old one, the old moral system inevitably lost its historic existence. However, in quite a long historical period, the old morality in various forms continues to play its functions and influences in social life, as sometimes even affects the entire community. Two causes can be used to illustrate this. On the one hand, the old social forces will make full use of it to wrestle with the new social forces, while what the new social forces want to solve is the pressing social, economic and political problems. On the other hand, the old morality, which plays a role in real life, exists widely as the social customs and personal inner beliefs. It is difficult for it to withdraw from the historical stage in a short term. Similarly, if the new morality wants to play its role in real life, it must be widely and deeply internalized into social, psychological and personal habits, which is a gradual long-term process. Therefore, in a new society, the old morality existing for quite a long period is a very common phenomenon in history. There is no exception even in the current socialist society.

1.1.2 The old social and economic relations are always conceiving and germinating a new moral sprout. Economic relations of any society, on the final phase of development process, are often conceiving the factors of 
future economic relations. Therefore, under the conditions that the old economic relations are still in dominant position, factors of moral system belonging to future society and classes will gradually come into beings on the basis of people's concepts and social communication. This indicates that moral reformation goes ahead of the changes of socio-economic relations. Marx and Engels, early before the stage when capitalism enters monopoly, do not only see the opposition between the proletarian morality and bourgeois morality, but also find the advanced nature and great future of proletarian morality.

\subsection{Morality can be relatively independent of having something direct with some other components of the superstructure}

Morality shows its relative independence in the relations with other factors of superstructure. Morality and other components of the superstructure reflect their social existence and are rooted in economic relations of certain society and ultimately subject to certain constraints of socio-economic conditions. However, this does not mean that morality when contacting with the other components of the superstructure, must be subject to social and economic relations. Morality, the same as other components of the superstructure, must reflect and serve certain social and economic relations. With its own unique features, in a different way and in different scope and from the angle of other ingredients of the superstructure, it reflects and meets some special requirements of economic relations. The other ingredients of superstructure in their own development, are constrained by the social and economic relations and directly affected, to varying degrees, by social morality. Similarly, morality, in its own development process, is not only constrained by social and economic relations, but also to varying degrees, directly affected by other components of superstructure. Among them, politics and laws have the most significant impacts on morality. The interaction of morality and politics shows that political change and moral growth can promote each other and moral system and political institution influence each other. Political guideline and policies affect the social morality with each other. The moral and legal interaction is as the following: both absorb each other in content and complement in social function and depend on each other in implementation. In addition, morality is independent of the interaction to arts and religion. In general, the interaction and influence of morality with other components of the superstructure occur in the scope of certain economic conditions.

\subsection{Morality has its own independent historical development process}

From the angle of the overall process of human history, it is based on the historical development of social and economic relations. As far as each concrete historical era and its pre-and-post connections are concerned, morality often shows some volatility and deviation relative to the historical process of economic relations. Some ethical factors, after the economic relations from which it originates is eliminated, can continue to exist for several generations while a new economic institutional system can not shape the corresponding moral system after its establishment. System of economic relations is not completely in line with the resulting morality in the development process. So the reasons that morality has such relatively independent history of the development process are many. First, morality of each era does not only reflect the specific socio-economic relations of then historical conditions, but also shows the continuation of some general social relations which has lasted for many generations. Second, morality of each era, as the independent part of division of the superstructure, the same as other like ideas, has the historical content passed down from its predecessors to be as the premise and starting point of its own, as is the characteristics of moral inheritance. Morality is part of the superstructure over economic relations. Therefore, requirements of new economic relations should be completely followed to critically inherit the old moral tradition. It is a long time before social and personal moral psychology and moral habits are changed. So in human history, the moral evolution is consistent with the overall historical process of social and economic development and at the same time has its own independent historical development.

\section{The dynamic roles of morality}

The moral dynamic functions are the outstanding performance of its relative independence. As for the dynamic roles of morality, there are two tendencies in the history of ethics. One is moral determinism, which overstates the roles of morality. It believes that social morality can determine the development of the whole society. Thus moral transformation is relied on social reform. The other extreme tendency is non-moral theory, which denies the dynamic roles of morality. It seems to them that rule of the jungle is the law of development of nature and human society, while morality is powerless, and totally useless. Marxist ethics is against the moral determinism, which exaggerates the moral function, and the non-moral theory denying the moral functions. According to materialist conception of history, about the dynamic roles of morality, we should make specific analyses.

\subsection{Marxist ethics fully endorses the major dynamic roles of morality on social and economic relations}

It believes that certain morality will counteract the whole process of socio-economic relations during which it is born in its own unique way once it comes into being. When the new economic relations develop and try to 
replace the old economic relations, morality arising from the economic relations will play a dynamic role. As social emotions and beliefs from a new society, the new ethics will show that the maintenance of the old economic relations is evil and unjust, and willing to support new economic relations for they are good and just. Thus, it strives to arouse the inner beliefs and public opinions of the people to eradicate the old economic relations and establish the new economic relations. When this new economic relations obtain a dominant position and set up the corresponding political system, morality resulting from it will form a complete system of principles and norms. The behavior of people will be introduced or bound in a scope of social order as much as possible in order to protect the consolidation and development of the new system of economic relations and political institution. The morality, shaped in the old economic relations and the corresponding political system, as a traditional psychology and custom, will hinder the establishment, consolidation and development of new economic relationships and the corresponding political system.

\subsection{The dynamic role of ethics has different features}

Moral reaction to socio-economic relations is a common phenomenon, but as for the nature of the role, there are differences between revolution and conservation, progress and reaction. This difference depends on what economic relations it maintains, and under what historical conditions it fulfills the task. As for different moral systems, generally speaking, to the economic relations in line with historical trends, the role of morality is progressive and revolutionary. On the contrary, to the economic relations losing historical necessity, the function of morality is either conservative or reactionary. As to the same moral system, when the economic relations it maintained is to liberate and develop productive forces, the nature of its role is progressive or revolutionary; when the economic relations it maintained has become barriers against the development of productive forces, especially has been replaced by new economic relations, the nature of moral role will turn to be conservative and reactionary.

\subsection{Morality is not a decisive force to transform the economic relations in class society}

As for measuring the dynamic role of morality, Marxist ethics does not consider it as a passive social factor and adopts a nihilistic attitude to it, nor a decisive force to change the socio-economic relations in a society of class antagonism. In the eyes of Marxist Ethics, the generation, development and replacement of a socio-economic relation has its historical inevitability and objective law. The fundamental driving force of its generation, development and replacement is the growth of productive forces. In a society of class confrontation, on the transformation and reformation of economic relations, morality can play a role of acceleration or deference. But the fundamental approach is the class struggle and violent revolution. On the issues of social development, particularly the issues concerning the reformation of social and economic relations, exaggerating the dynamic roles of ethics is a kind of hypocrisy and deception.

Socialist morality, generated on the basis of socialist public economy, reflects the essential characteristics of socialism. The dominant moral system in the socialist society, derived from the proletarian morality, has become the standard of conduct for the people to build up a new life in the historical period of socialism. In the process of the establishment and development of socialism, socialist morality has all the time played a progressive role, and taken consolidating and improving socialism, and realizing communism as its objective. Socialist ethics, in the socialist spiritual civilization with communist ideology as the core, has an important role. Its dynamic functions for social and material living are much more extensive and profound than any other moral systems in history. The socialist moral system, which has been improved constantly, regulates the relations between individuals and society as a whole and that among people, guide people to consciously abide by the social order, and promote the consolidation, development and improvement of socio-economic relations based on public ownership and the corresponding political and legal system. At present, with the continuous development of the socialist market economy and the continuous consolidation of the basic economic system, the corresponding moral system is constantly perfected in the transition. Socialist moral construction has become the basic project of the socialist cultural construction. With deep development of the moral education and moral practice, the socialist morality will play an increasingly active role in building the socialist material civilization and spiritual civilization.

\section{References}

Luo, Guojie. (1982). Marxist Ethics. Beijing: The People's Publishing House.

Selected Works of Marks and Engels. Volume 3\& 4. (1972). Beijing: The People's Publishing House.

Yuan, Zhaochun. (2008). Higher education law and professional ethics of teachers. Jinan: Shandong University Press. 